\title{
Pemberian ekstrak daging ayam broiler meningkatkan berat badan dan berat lemak viseral serta meningkatkan produksi rambut pada anak tikus (Rattus norvegicus) jantan galur Wistar
}

\author{
${ }^{1}$ Corry P. Syafii, ${ }^{2}$ Wimpie Pangkahila, ${ }^{3}$ IGM Aman
}

\author{
${ }^{1}$ Program Pascasarjana Anti-Aging Medicine \\ ${ }^{2}$ Departemen Andrologi dan Seksologi \\ ${ }^{3}$ Departemen Farmakologi \\ Fakultas Kedokteran Universitas Udayana Denpasar \\ E-mail: corrygigid@gmail.com
}

\begin{abstract}
Despite the estrogen and progesterone content found in commercialy prepared fried chicken, these types of restaurants are proliferating worldwide. This study was aimed to prove that oral broiler meat extract increased body weight, visceral fat mass, and hair follicles in young male Wistar rat (Rattus norvegicus). This was a completely randomized experimental study with the post-test only control group design. Subject were 36 healthy male rats (Rattus norvegicus), Wistar strain, aged 1.5 months (equivalent to human of 13 years old), weighing 80-150 g, divided into two groups of 18 rats each. The control group (P0) was treated with distilled water as placebo for 21 days and the treatment group (P1) was treated with oral broiler meat extract of $3.6 \mathrm{~g} / \mathrm{rat} / \mathrm{day}$ for 21 days. After 21-day treatment, rats were weighed and were terminated for observation of their visceral fat mass meanwhile their skin tissues were examined histologically for the numbers of hair follicles. The results showed that the mean body weight after 21-day treatment in the P0 group was $173.94 \pm 4.976 \mathrm{~g}$, whereas in the P1 group was $195.94 \pm 4.869 \mathrm{~g}(P<0.01)$. The mean visceral fat mass after 21 days of treatment in the $\mathrm{P} 0$ group was $0.356 \pm 0.0784 \mathrm{~g}$ whereas in the $\mathrm{P} 1$ group was $0.567 \pm 0.1138 \mathrm{~g}(P$ $<0.01)$. The mean number of hair follicles after 21-day treatment in the P0 group was $23.78 \pm 1.629$ follicles at four fields of view meanwhile in the P1 group was $31.56 \pm 2.332$ follicles at four fields of view $(P<0.01)$. Conclusion: Oral broiler meat extract could increase body weight, visceral fat mass, and hair follicles in young male rat (Rattus norvegicus) of Wistar strain.
\end{abstract}

Keywords: broiler meat, body weight, visceral fat

\begin{abstract}
Abstrak: Umumnya daging ayam broiler mengandung estrogen dan progesteron namun restoran cepat saji yang menyajikan menu ayam goreng olahan telah menularluas di seluruh dunia. Penelitian ini bertujuan untuk membuktikan bahwa pemberian ekstrak daging ayam broiler dapat meningkatkan berat badan, berat lemak viseral, dan pertumbuhan rambut anak tikus (rattus norvegicus) jantan galur Wistar. Jenis penelitian ialah eksperimental completely randomized dengan posttest only control group design. Subyek penelitian ialah 36 ekor tikus putih (Rattus norvegicus) jantan, galur Wistar, sehat, umur 1,5 bulan (sesuai dengan anak usia 13 tahun), dengan berat badan 80-150 gr yang dibagi menjadi 2 (dua) kelompok masingmasing berjumlah 18 ekor tikus. Kelompok kontrol (P0) diberikan plasebo berupa aquades selama 21 hari, dan kelompok perlakuan (P1) diberikan ekstrak daging ayam broiler dosis 3,6 gr/ekor/hari selama 21 hari. Setelah 21 hari perlakuan seluruh tikus diukur berat badannya, dan tikus diterminasi untuk pemeriksaan berat lemak viseral dan organ kulit diproses untuk pemeriksaan folikel rambut. Hasil penelitian menunjukkan rerata berat badan sesudah 21 hari perlakuan kelompok P0 ialah 173,94 $\pm 4,976$ gr, sedangkan pada kelompok P1 195,94 $\pm 4,869$ gr $(P<0,01)$. Rerata berat lemak viseral sesudah 21 hari perlakuan kelompok P0 ialah $0,356 \pm 0,0784 \mathrm{gr}$, sedangkan pada kelompok P1 $0,567 \pm 0,1138$ gr $(P<0,01)$. Rerata jumlah
\end{abstract}


folikel rambut setelah 21 hari perlakuan pada kelompok P0 ialah $23,78 \pm 1,629$ folikel pada 4 lapang pandang, sedangkan pada kelompok P1 31,56 $\pm 2,332$ folikel pada 4 lapang pandang $(P$ $<0,01)$. Simpulan: Ekstrak daging ayam broiler dapat meningkatkan berat badan, berat lemak viseral, dan pertumbuhan rambut anak tikus (Rattus norvegicus) jantan galur Wistar.

Kata kunci: daging ayam broiler, berat badan, lemak viseral

Semakin bertambahnya restoran cepat saji yang menyediakan berbagai macam menu dan jenis makanan yang tentunya dikemas menarik, maka dengan cepat menjadi pilihan orang tua untuk memberikan variasi makanan pada anaknya, apalagi jika orang tua bekerja yang kadang tidak mempunyai banyak waktu untuk memasak. Saat ini sebagian besar ayam pedaging (broiler) diberi hormone implant untuk mendapatkan hasil produksi yang lebih banyak dan ayam tumbuh lebih cepat. Menurut perkiraan pada tahun 1956, sekitar dua pertiga dari ayam ternak di seluruh negara bagian Amerika menggunakan hormon dietilstibesterol. ${ }^{1}$ Hasil ini didukung dengan studi pendahuluan yang menunjukkan bahwa estrogen terdeteksi sebesar 0,522 pg/gr pada daging bagian paha, $0,683 \mathrm{pg} / \mathrm{gr}$ pada daging bagian dada, dan $0,796 \mathrm{pg} / \mathrm{gr}$ pada daging bagian sayap. Selain itu, untuk progesteron terdeteksi sebesar $0,018 \mathrm{pg} / \mathrm{gr}$ pada daging bagian paha, $0,024 \mathrm{pg} / \mathrm{gr}$ pada daging bagian dada, dan 0,047 pg/gr pada daging bagian sayap. Daging hasil analisis tersebut dibeli di restoran siap saji yang khusus menjual ayam goreng.

Aryani $^{2}$ menyatakan bahwa pemberian bahan makanan yang mengandung estrogen jelas akan meningkatkan kadar hormon tersebut di dalam darah. Hasil penelitian tersebut menyebutkan bahwa pemberian susu suplemen tinggi protein whey yang mengandung fitoestrogen $(0,092 \mathrm{mg} / 100 \mathrm{gr})$ dan estradiol $(0,025 \mathrm{mg} / 100 \mathrm{gr})$ dapat meningkatkan kadar estrogen. Didukung oleh hasil penelitian Bonora $^{3}$ yang menggunakan susu pengganti cair yang mengandung estrogen sebesar $4,87 \mathrm{pg} / \mathrm{gr}$ dan progesteron sebesar $5,11 \mathrm{pg} / \mathrm{gr}$ selama 21 hari pada tikus lepas sapih dapat meningkatkan kadar estrogen dari 0,04 $\pm 0,008 \mathrm{ng} / \mathrm{ml}$ menjadi 0,05 $\pm 0,006$ $\mathrm{ng} / \mathrm{ml}$. Selain itu Bonora ${ }^{3}$ juga mengguna- kan susu lain yang terbukti mengandung estrogen sebesar $4,98 \mathrm{pg} / \mathrm{gr}$ dan progesteron sebesar 5,84 pg/gr dapat meningkatkan kadar estrogen dari $0,04 \pm 0,008 \mathrm{ng} / \mathrm{ml}$ menjadi $0,06 \pm 0,011$ $\mathrm{ng} / \mathrm{ml}$.

Obesitas dan peningkatan berat badan merupakan salah satu akibat dari meningkatnya kadar hormon anabolik termasuk estrogen di dalam darah. Peningkatan berat badan akibat tingginya kadar estrogen dikarenakan terjadi peningkatan lemak viseral. Obesitas pada anak dapat terjadi karena mendapat paparan hormon estrogen eksternal pada masa balita, dan dapat mengalami pubertas precox. ${ }^{4,5}$ Tingginya kadar progesteron juga dapat memengaruhi berat badan dan kandungan lemak viseral. Hormon progesteron merangsang pusat pengendali nafsu makan di hipotalamus yang menyebabkan individu makan lebih daripada biasanya. Hormon progesteron memengaruhi perubahan karbohidrat dan gula menjadi lemak, sehingga lemak di bawah kulit bertambah. Selain itu hormon progesteron juga menyebabkan nafsu makan bertambah dan menurunkan aktivitas fisik. ${ }^{6}$ Bonora ${ }^{3}$ menyatakan bahwa hampir semua anak berusia 1-10 tahun pernah diberikan makanan pengganti cair yang mengandung estrogen dan progesteron, baik secara teratur maupun tidak. Pada suatu penelitian didapatkan pemberian asupan makanan yang mengandung estrogen akan menghambat produksi rambut. $^{7}$

Berdasarkan latar belakang di atas maka dilakukan penelitian menggunakan ekstrak daging ayam broiler terhadap anak tikus (Rattus norvegicus) jantan berumur 45 hari yang sudah memasuki masa pubertas $^{8}$ yang disetarakan dengan anak berusia 13 tahun. ${ }^{9}$ 


\section{METODE PENELITIAN}

Penelitian ini bertujuan untuk menguji efek pemberian ekstrak daging ayam broiler terhadap berat badan, lemak viseral, dan pertumbuhan rambut anak tikus (Rattus norvegicus) jantan galur Wistar dilakukan dengan posttest only control group design. ${ }^{10}$

Subjek penelitian ini ialah 36 ekor tikus putih (Rattus norvegicus) jantan, galur Wistar, kondisi tikus sehat, umur 1,5 bulan (sesuai dengan anak usia 13 tahun), dengan berat badan 80-150 gr. Subyek penelitian dibagi menjadi dua kelompok, masing-masing berjumlah 18 ekor tikus, yaitu kelompok kontrol (P0) yang diberikan plasebo berupa aquades selama 21 hari, dan kelompok perlakuan (P1) yang diberikan ekstrak daging ayam broiler dosis 3,6 gr/ekor/hari selama 21 hari.

Setelah 21 hari perlakuan dilakukan pemeriksaan berat badan, berat lemak viseral abdominal, dan pertumbuhan rambut yang dinilai secara histologik pada sediaan jaringan kulit yang dipulas dengan hematoksilin-eosin (HE) (pembesaran 400x).

\section{HASIL DAN BAHASAN}

Hasil penelitian menunjukkan rerata berat badan setelah 21 hari perlakuan pada kelompok kontrol (P0) ialah 173,94 $\pm 4,976$ gr, sedangkan pada kelompok P1 sebesar $195,94 \pm 4,869$ gram $(P<0,01)$. Rerata berat lemak viseral abdominal setelah 21 hari perlakuan kelompok P0 ialah 0,356 $\pm 0,0784$ gr, sedangkan pada kelompok P1 sebesar $0,567 \pm 0,1138$ gr $(P<0,01)$. Rerata jumlah folikel rambut setelah 21 hari perlakuan pada kelompok P0 ialah 23,78 $\pm 1,629$ folikel pada 4 lapang pandang, sedangkan pada kelompok P1 ialah 31,56 $\pm 2,332$ folikel pada 4 lapang pandang $(P<0,01)$. Hal ini menunjukkan bahwa setelah 21 hari perlakuan (posttest) terdapat perbedaan yang bermakna dari berat badan, berat lemak viseral abdominal, dan jumlah folikel rambut antar kelompok kontrol (P0) dan kelompok perlakuan (P1) (Tabel 1, Gambar 1 dan 2).

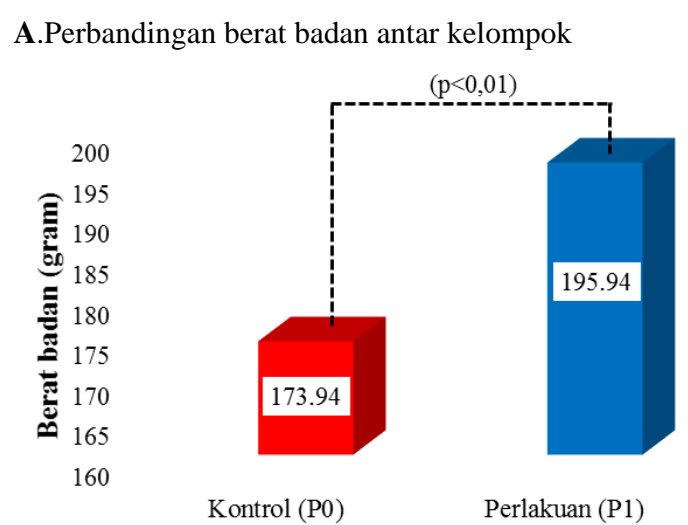

B.Perbandingan berat lemak viseral antar kelompok

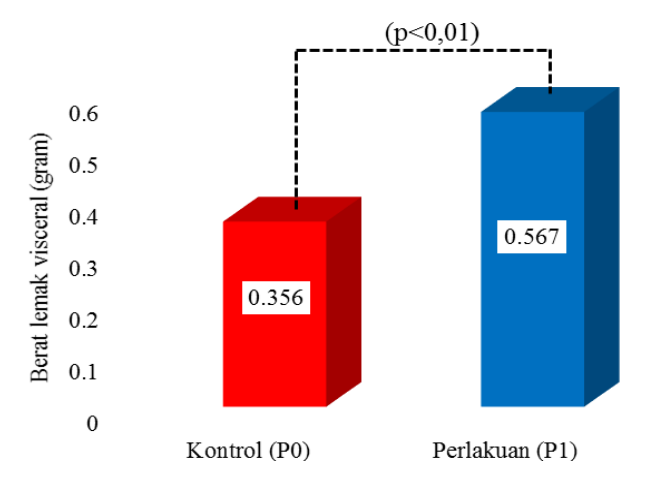

C.Perbandingan jumlah folikel antar kelompok

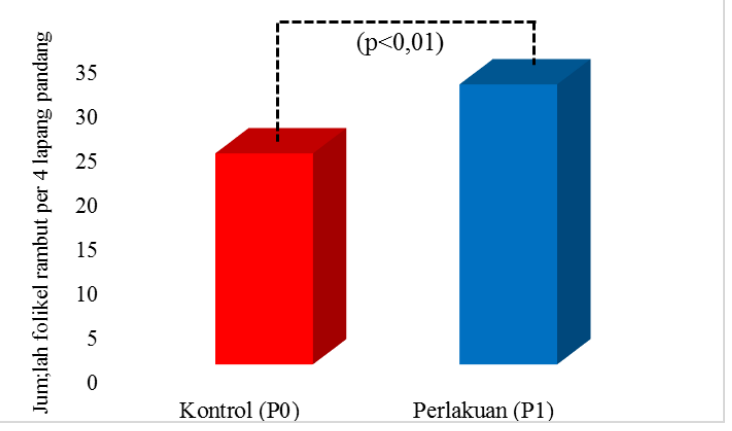

Gambar 1. Perbandingan antara kelompok P0 dan P1. A, Berat badan; B, Berat lemak viseral; C, Perbandingan jumlah folikel antar kelompok

Hasil penelitian ini menunjukkan bahwa pemberian ekstrak ayam broiler selama 21 hari dapat menyebabkan peningkatan berat badan akibat penumpukan depot lemak viseral pada daerah abdomen. Hal ini terkait kandungan hormon anabolik pada ekstrak ayam broiler yang digunakan. 
Tabel 1. Rerata nilai variabel antar kelompok setelah perlakuan

\begin{tabular}{cccccc}
\hline Variabel & Kelompok & Rerata & SB & $\boldsymbol{t}$ & $\boldsymbol{P}$ \\
\hline \multirow{2}{*}{ Berat badan (gr) } & P0 & 173,94 & 4,976 & \multirow{2}{*}{$-13,408$} & \multirow{2}{*}{0,000} \\
& P1 & 195,94 & 4,869 & & \\
Berat lemak viseral (gr) & P0 & 0,356 & 0,0784 & $-6,483$ & 0,000 \\
Folikel rambut pada 4 & P0 & 0,567 & 0,1138 & & \\
lapang pandang & P1 & 23,78 & 1,629 & $-11,601$ & 0 \\
\hline
\end{tabular}

$\mathrm{SB}=$ Simpangan Baku; $t=t$-test $P=$ signifikansi
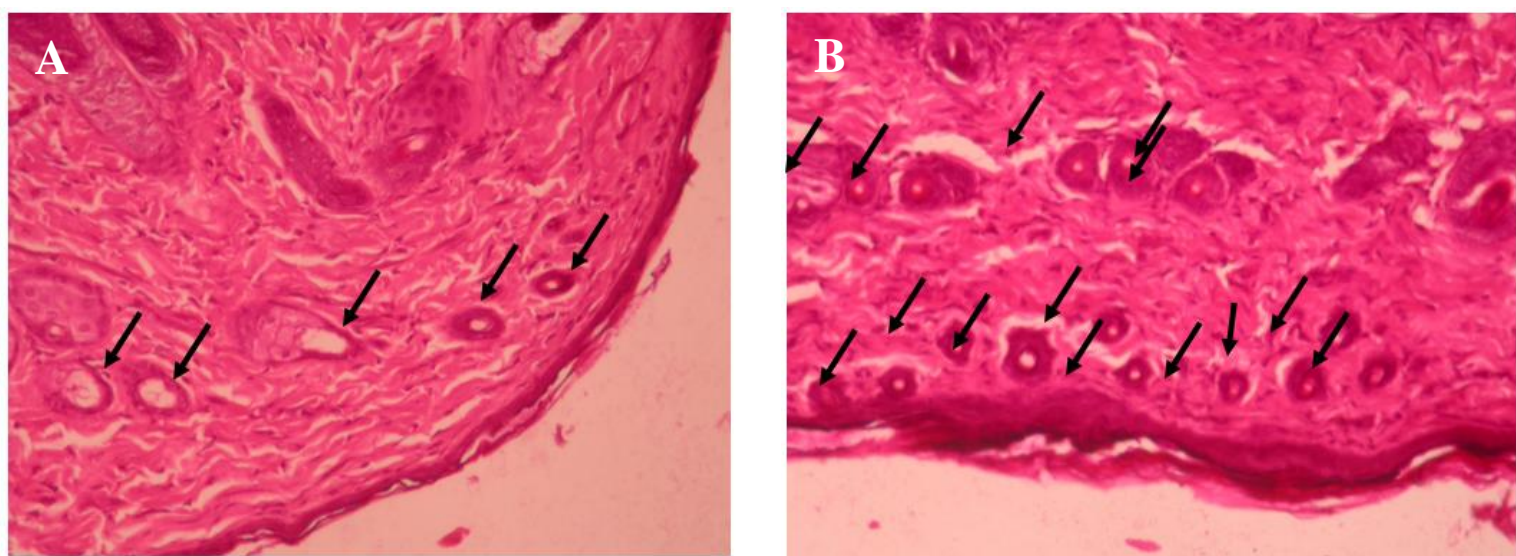

Gambar 2. Perbandingan jumlah folikel rambut. A, Kelompok kontrol (P0); B, Kelompok perlakuan (P1). Anak panah menunjukkan folikel rambut (Pewarnaan HE, pembesaran 400x)

Hasil penelitian ini sejalan dengan penelitian oleh Bonora ${ }^{3}$ yang mendapatkan pemberian makanan pengganti cair yang mengandung estrogen dan progesteron dapat meningkatkan berat badan, kadar hormon estrogen, dan kadar hormon progesteron pada anak tikus jantan (Rattus norvegicus) galur Wistar. Penelitian lain yang selaras oleh Cox dan King ${ }^{11}$ juga melaporkan bahwa pemberian estrogen dapat meningkatkan asupan makanan dan berat badan pada tikus yang telah dilakukan ovariektomi sehingga kadar estrogen menurun.

Tingginya kadar progesteron dapat memengaruhi berat badan dan kandungan lemak viseral. Hormon ini merangsang pusat pengendali nafsu makan di hipotalamus yang menyebabkan individu akan makan lebih daripada biasanya. Hormon progesteron juga memengaruhi perubahan karbohidrat dan gula menjadi lemak, sehingga lemak di bawah kulit bertambah. Selain itu hormon progesteron juga menyebabkan nafsu makan bertambah dan menurunkan aktivitas fisik. ${ }^{6}$ Hal ini didukung oleh pemeriksaan jumlah pakan yang dikonsumsi oleh hewan coba selama penelitian berlangsung. Analisis sisa pakan menunjukkan bahwa terjadi peningkatan jumlah konsumsi pakan pada kelompok perlakuan (P1).

Obesitas pada anak dapat terjadi karena mendapat paparan hormon estrogen eksternal pada masa balita, dan dapat mengalami pubertas precox. ${ }^{4,5}$ Faktor risiko terjadinya hal tersebut antara lain: obesitas, tumor kelenjar adrenal atau kelenjar pituitari yang menghasilkan estrogen atau testosteron, McCune-Albright syndrome, kista ovarium, tumor ovarium, tumor sel Leydig yang menghasilkan testosteron, mutasi gen (gonadotropin-independent familial sexual precocity, cacat pada gen yang menyebabkan produksi dini testosteron pada anak laki-laki berusia 1-4 
tahun) atau terpapar estrogen dan testosteron secara eksternal berupa kontak dengan krim topikal yang mengandung hormon estrogen atau testosteron, atau substansi lain yang mengandung hormon seperti obat, makanan, atau minuman. 5,12,13 Menurut Bonora, ${ }^{3}$ hampir semua anak yang mengonsumsi makanan pengganti cair yang mengandung estrogen dan progesteron secara teratur terlihat memiliki berat badan berlebih, dan pada sebagian anak perempuan yang diberikan makanan pengganti cair diketahui mengalami early menarche, bahkan pada beberapa anak pria berusia 6 tahun tumbuh bulu pada kaki.

Penelitian mengenai hubungan estrogen dengan folikel rambut menjelaskan bahwa terdapat reseptor sex steroid hormone pada folikel rambut dan interaksi ini terkait sistem interaksi neuroektodermal-mesoderm. Dari sebuah penelitian ditemukan bahwa estrogen berefek penghambatan yang cukup besar pada siklus foliket rambut, yaitu dengan menginhibisi irama sirkadian telogen. Pada hewan model tikus, estrogen topikal dapat menghambat telogen dan menginduksi katagen. Seperti halnya estrogen, kortisol bahkan dapat disintesis di folikel rambut itu sendiri dan akan merangsang reseptor glukokortikoid. $^{14}$

Beberapa penelitian menunjukkan bahwa pemberian estrogen dapat menghambat proses pertumbuhan rambut, dan pemberian inhibitor reseptor estrogen ICI 182.780 dapat memacu pertumbuhan rambut. Selain itu tikus yang dilakukan ovariektomi mengalami hambatan pertumbuhan rambut ditandai dengan transisi dari fase telogen menjadi fase anagen. Penelitian ini mengindikasikan bahwa estrogen menghambat transisi dari fase telogen ke fase anagen pada siklus folikel rambut sehingga menghambat proses pertumbuhan rambut. ${ }^{15,16}$ Ohnemus et al. ${ }^{7}$ menyatakan bahwa pemberian estrogen akan menghambat produksi rambut.

Dari hasil penelitian-penelitian tersebut dapat disimpulkan bahwa pemberian estrogen akan menghambat produksi rambut. Penelitian ini menunjukkan hasil yang bertolak belakang dengan hasil penelitian yang telah dipaparkan di atas. Hasil penelitian menunjukkan rerata jumlah folikel rambut setelah 21 hari perlakuan kelompok kontrol (P0) ialah 23,78 $\pm 1,629$ folikel pada 4 lapang pandang, sedangkan pada kelompok P1 ialah 31,56 $\pm 2,332$ folikel pada 4 lapang pandang $(P<0,001)$ (Gambar 2 dan 3). Hal ini menunjukkan bahwa pemberian ekstrak ayam broiler yang mengandung hormon estrogen dan progesteron selama 21 hari perlakuan dapat meningkatkan jumlah folikel rambut.

Hasil penelitian ini sejalan dengan hasil penelitian lainnya yang menggunakan terapi estrogen topikal untuk meningkatkan produksi rambut pada pasien kemoterapi yang mengalami alopesia. ${ }^{17}$ Sebuah penelitian membuktikan bahwa estrogen menginduksi folikel rambut pada fase katagen untuk mengalami distrofi dan digantikan dengan folikel fase anagen (transisi katagen-anagen); dengan kata lain meningkatkan pertumbuhan rambut. Sebaliknya pemberian estrogen inhibitor ICI 182.780 cenderung menghambat pertumbuhan rambut dengan menginduksi folikel rambut untuk transisi menuju fase katagen. $^{18}$ Secara singkat, pemberian estrogen dapat meningkatkan jumlah folikel rambut yang normal pada fase anagen dan meningkatkan produksi rambut. ${ }^{17,18}$

Meskipun efek estrogen terhadap folikel rambut dapat diamati pada hormon steroid lainnya, yaitu glukokortikosteroid dan calcitriol, mekanisme molekuler yang mendasari efek hormon-hormon ini terhadap folikel rambut belum jelas. ${ }^{17}$ Efek terhadap jalur molekul sinyal yang kompleks dari dua reseptor estrogen ER $\alpha$ dan ER $\beta$, interaksi yang rumit dengan agonis dan antagonis, beberapa mekanisme sinyal yang saling tumpang tindih (crosstalk), dan sejumlah besar molekul yang terlibat dalam ER signaling (coactivation, corepression) memerlukan penelitian lebih lanjut yang ekstensif ${ }^{19-21}$ agar dapat memahami lebih detil mengenai respon seluler terhadap rangsangan pada ligan ER dalam folikel rambut yang berinteraksi 
dengan jalur molekuler intrinsik untuk siklus folikel rambut. ${ }^{17}$

Sebuah penelitian yang mengeksplorasi intervensi farmakologis terhadap manipulasi siklus rambut klinis, mulai dari alopecia androgenetik dan hirsutisme melalui telogen effluvium untuk alopesia akibat kemoterapi menimbulkan pertanyaan rumit dan tantangan klinis yang belum terpecahkan. ${ }^{17}$ Di masa depan diharapkan adanya terapi hormon untuk gangguan pertumbuhan rambut. ${ }^{14}$

Sebelum dilanjutkan ke dalam aplikasi klinis, perlu dilakukan penelitian lanjut yang lebih ekstensif mengingat hasil penelitian yang tidak konsisten yaitu apakah estrogen meningkatkan atau cenderung menurunkan produksi rambut.

\section{SIMPULAN}

Berdasarkan hasil penelitian ini dapat disimpulkan bahwa pemberian ekstrak daging ayam broiler dapat meningkatkan berat badan, berat lemak viseral, dan pertumbuhan rambut anak tikus (Rattus norvegicus) jantan galur Wistar.

\section{DAFTAR PUSTAKA}

1. Swan SH, Liu F, Overstreet JW, Brazil C, Skakkebaek NE. Growth hormones fed to beef cattle damage human health: Semen quality of fertile US males in relation to their mothers' beef consumption during pregnancy. Hum Reprod. 2007;22(6):1497-503.

2. Aryani S. Pemberian susu suplemen tinggi protein whey (L-Men Platinum) dapat meningkatkan kadar testosteron dan estrogen pada tikus putih (Rattus norvegicus) jantan dengan aktivitas fisik sedang [Tesis]. Denpasar: Program Pascasarjana Magister Biomedik Universitas Udayana; 2015.

3. Bonora LS. Pemberian makanan pengganti cair meningkatkan berat badan serta kadar hormon estrogen dan progesteron pada anak tikus (Rattus norvegicus) jantan galur Wistar [Tesis]. Denpasar: Program Pascasarjana Magister Biomedik Universitas Udayana; 2015.

4. Marcovecchio ML, Chiarelli F. Obesity and growth during childhood and puberty. 2013. World Review Nutrition Diet. [cited 2016 Aug 18]. Available from: http://www.researchgate.net/publicatio n/235689372_Obesity_and_Growth_du ring_C hildhood_and_Puberty.

5. Staff of Mayo Clinic. Definition of precocious puberty. 2014. [cited 2016 Aug 20]. Available from: http: //mayoclinic.com/article/precociouspub erty-definition.

6. Lopez LM, Edelman A, Chen M, Otterness C, Trussell J, Helmerhorst FM. Progestin-only contraceptives: effects on weight. Cochrane Database Syst Rev. 2013;7: CD008815.

7. Ohnemus $U$, Uenalan $M$, Inzunza $J$, Gustafsson JA, Paus R. The hair follicle as an estrogen target and source. Endocr Rev. 2006;27(6):677-706.

8. Armitage D. 2004. Rattus norvegicus brown rat (also: Norway rat). [cited 2016 Aug 20]. Available from: http://genomics. senescence.info/species/.

9. Budhy. 2010. Laporan lengkap pemeliharaan mencit. [cited 2016 Aug 20]. Available from: http://budhymcn.blogspot.com/ 2010/12/laporan-lengkappemeliharaan-mencit.html.

10. Federer W. Statistics and Society: Data Collection and Interpretation (2nd ed). New York: Marcel Dekker, 2008.

11. Cox VC, King JM. The effects of estradiol on food intake and weight in ovariectomized rats with amygdaloid lesions. Physiological Psychology. 1974;2(3):371-3.

12. Sinha S. Precocious pseudopuberty. 2013. Kemp S, chief editor. [cited 2016 Aug 18]. Available from: http://emedicine. medscape.com/article/923876overview.

13. Kaplowitz PB. Precocious Puberty Workup. 2014. Kemp S, chief editor. [cited 2016 Aug 18]. Available from: http:// emedicine.medscape.com/article/92400 2-workup.

14. Ohnemus U, Uenalan $M$, Conrad F, Handjiski B, Mecklenburg L, Nakamura M, et al. Hair cycle control by estrogens: catagen induction via estrogen receptor (ER)-alpha is checked by ER beta signaling. Endocrinol. 2005;146(3):1214-25.

15. Chanda S, Robinette CL, Couse JF, Smart 
RC. 17beta-estradiol and ICI-182780 regulate the hair follicle cycle in mice through an estrogen receptor-alpha pathway. Am J Physiol Endocrinol Metab. 2000;278:E202-E210.

16. Movérare S, Lindberg MK, Faergemann J, Gustafsson JA, Ohlsson C. Estrogen receptor $\alpha$, but not estrogen receptor $\beta$, is involved in the regulation of the hair follicle cycling as well as the thickness of epidermis in male mice. J Invest Dermatol. 2002;119:1053-8.

17. Ohnemus U, Unalan M, Handjiski B, Paus R. Topical estrogen accelerates hair regrowth in mice after chemotherapyinduced alopecia by favoring the dystrophic catagen response pathway to damage. J Invest Dermatol. 2004; 122(1):7-13.

18. Müller-Röver S, Handjiski B, Paus R. Pathways of chemotherapy-induced alopecia: New criteria for the diagnosis of hair follicle dystrophy. Arch Dermatol Res. 202;294:40.

19. Nilsson S, Gustafsson JA. Estrogen receptor transcription and transactivation. Basic aspects of estrogen action. Cancer Res. 2000;2:360-6.

20. Nilsson S, Makela S, Treuter E. Mechanisms of estrogen action. Physiol Rev. 2001;81:1535-65.

21. Thornton MJ. The biological actions of estrogens on skin. Exp Dermatol. 2002;11:487-502. 